\title{
INDEX MEDICO-PSYCHOLOGICUS.
}

Acute delirious insanity, The treatment of. G. M. Roberteon. Bdin. Hosp. Rop., 1893, i., 825-838.

Lep., 1893, 1oute delirions mani

Paul, 1893, xiii., 467-469.

Paute delirious mania. G. L. Sinolair. Internat. Olin., Phila., 1898, 3 s., ii., 135-143.

Aoute manis following rupture of the reotum by enems thirteen daye after ovariotomy. A. C. Butler-Smythe. J. Ment. Bc., Lond., 1893, xxeix., 889'397.

Aoute insanity, On the early stages of. T. C. Bhaw. St. Barth. Hosp. Bop., Lond., 1893, xxix., 109.128.

with sexual perversion, Notes on a case of. W. C. Sullivan. J. Mont. So., Lond., 1893, xxxix., 225.

Acute mania. Some suggestions as to the treatment of acute mania. J. W. Givens. J. Am. M. Ass., Chicago, 1894, xxiii., 153.

(Case of), septicrmia; death. A. W. Anderson. Brit. M. J., Lond., $1893, \mathrm{i} .1110$.

Address before the fiftieth annual meeting of the Amerioan Medioo-Peyohological Association, held in Philadelphia, May 16th, 1894. B. W. Mitchell. J. Nerv. and Ment. Dis., N.Y., 1894, xxi., 413-437.

Administration. The lanacy administration of Scotland, 1857-1892. T. 8. Clouston. Am. J. Insan., Utics, N.Y., 1893-4, l., 186-197.

Ages and death-rates of lunatics in the district where acoumulation of lunation is most adranced. T. A. Chapman. J. Ment. So., Lond., 1894, xl., 885-893. $4 \mathrm{ch}$.

Alcoholism. The relation of the abuse of alcohol to mental diseases. B. H. Noott. Lancet, Lond., 1893, ii., 739-741.

The effect of alooholio intorication upon the human brain and its reler tion to the theories of heredity and evolution. A. Forel. Quart. J. Inebr., Hartford, 1893, xv., 204-221.

Contriburione allo studio della pazzia transitoria da avrelenamento alocolioo. A. Marro. Ann. di freniat., eto., Torivo, 1891-2, iii., 257-874.

- Alcoholism in New York and the classification of inebriates. O. L. Dana. Am. J. Insan., Utica, N.Y., 1893-4, 1., 29-33.

- An abstract of the rational treatment of drink habit cases. J. G. Road. West. M. Reporter, Chicago, 1893, xv., 73-75.

The ætiology and therapentics of alcoholio inebriety. L. D. Macon. Brooklyn M. J., 1893, vii., 496-503.

The control of inebriates. F. MacD. Cosgrave. Tr. Roj. Aoad. M. Ireland, Dabl., 1891.2, x., 367-379.

Beporter, Phila., 1893, lxix., 623-628.

The Keeley cure of alcoholism. J. W. Roberteon. Paoifio M. J., Ban. Eran., 1893, xxxvi., 286-293. Also Tr. M. Soc. Calif., Ban. Bran., 1893, rxiii., 194-204

- Keeleyism and Keeley methods, with some statiotice. B. D. Hrans. Med. News, Phila., 1893, Jxii., 477-484.

Hot water in acute alcoholism. 8. W. Burson. N. Am. Pract., Chicago, 1893, v., 155-158.

Some peculiar effects from large doses of hyosoine in a case of acute alcoholism. J. P. Fiske. Med. Reo., N.Y., 1893, xliv., 142.

- The bichloride of gold treatrient for dipsomania. L. E. Reeley. Chicago M. R3corder, 1893, iv., $112-414$. 
Alooholism. The so-called bi-obloride treatment; its relation to the medica I profetsion and to the people. F. F. Daniel. Texas Banitarian, Austin, 1892-3, ii., 365-374.

Nitrate of strychnine in alcoholism. J. B. MoConnell. N. York M. J., 1893, lvii., 612-616.

Report of the inebriates legislation committee. Brit. M. J., Iond., 1893, ii., 273.

$\Delta$ merioan inebriate asylums. T. D. Crothers. J. Am. M. Ass., Chicago, 1893, xxi., 471-477.

Alimentary affections in the insane, Concerning some of the. Amelia Gilmore. Phila. Hosp. Bop., 1893, ii., 198-205.

$\Delta$ morican medico-psychological literature (a half-century of). G. A. Blumer. $\Delta \mathrm{m}$. J. Insan, Chioago, 1894-5, li., 40-50.

- Association. Bome remarks on the address delivered to the $\Delta$ merioan Psychological Association, by 8. Weir Mitchell, M.D., May 16, 1894. W. Channing. Ibid., 171-181.

Artificial feeding of the insane. J. Neil. Brit. M. J., Lond., 1894, i., 888.

- in acnte melancholia. J. Neil. Ibid., 183.

Asylums. Insane asylum management. S. A. Cunningham. Cincin. LancotClinic, 1894, n.8., xxxiii., 520-522.

- Lanatio asplums, their organisation and management. Charles Meroier. Lond., 1894, C. Griffi n \& Co. 315 p., 80.

The effect of the recent change in county government on asylums and the insane. T. W. MoDowall. Brit. M. J., Lond., 1893, ii., 358-364.

The great aojlum of Alt Scherbitz, near Leipzig. C. Norman. J. Ment. So., Loud., 1894, xl., 494.

"The medical service of the lunatio asylums of England. Med. Mag., Lond., 1894-5, iii., 141-151.

N.Y., 1893-4, l., 351-361. dent. L. A. Weatherly. J. Ment. Sc., Lond., 1894, xl, 345-354.

- Some remarks on the new form of the Omagh asylum. G. F. West. J. Ment. So., Lond., 1893, xxxix., 197-199.

- Une visite à deux asiles d'aliénés à l'étranger; 1. Maniob, en Bavidre; 2. a Vienne, en Antriche. L. Puteanx. Assistance, Par, 1893, iii., 225.231.

Auto-intorication in mental diseases. Régis and Chevalier-Lavaure. Med. Week, Par., 1898, i., 373-875.

- Des auto-intoxications dans les maladies mentales. J. 86glas. Arch. gén. de mód., Par., 1893, ii., 532-555.

Des auto-intorications dans les maladies mentales. Régis et ChevalierLavaure. [Rap.] Ann. de psychiat. et d'hypnol., Par., 1893, n.s., iii., 261-274.

Ueber Autointoxications-Psychosen. D. F. Jacobson. Allg. Ztechr. f. Peyohiat., etc., Berl., 1894, li., 379-406.

Antomatio acts. Contribution \&̀ l'étude des actes purement antomatiques obez les aliénés. M. Bombarda. Rev. neurol., Par., 1893, i., 490-495.

Blood in insanity. Sulla isotonia del sangue negli alienati. C. Agostini. Riv. oper di freniat., Reggio-Emilia, 1892, xviii., 483-497.

On the value of examination of the blod of the insane. J. $A$. Houston. Boston M. \& 8. J., 1894, cxxx., 58-56.

The blood in melencholis, and tho effeot of systematic tonic trestment. W. Steele. $\Delta m$. J. Insan., Utica, N. Y., 1892-3, xlix., 604-610.

Bodily disease as a canse of insanity. E. Du B. Bondurant. Tr. M. Ass. Alabama, Montgomery, 1898, 303-314. 
Body weight and mental improvement. A. R. Moulton. Am. J. Inean, Chicago, 1894-5, li., 209-220.

Brain. On the typical microscopic lesions found in the brain in insanity. T. 8. Olouston, J. Middlemass, and W. F. Robertson. J. Ment. Bo, Lond., 1894, xl., 665-670.

- from miorocephalio idiot, with extraordinary smallness of frontal lobes. J. Wiglesworth. Liverpool M. Chir. J., 1893, xiii., 501.

Anstomisahe Stadien an Gehirnen Geisteskranker. H. Sohlöa. Jahrb. f. Psychiat., Leips. o. Wien, 1893-4, xii., 167-337, 6 pl.

- in mental disease. Bulle fine alterazioni della cortecia cerebralo in aloune malattie mentali. R. Colella. Ann. di nevrol., Torino, 1892, n.e., x., 812-314,

- - in mental diseases. Sur les alterations histologiques de l'ecore órrébrale dans quelques maladies mentalis. R. Colella Arch. ital. de biol., Turin, 1898-4, xx., 216-218.

Calrarium from a case of circular insanity. L. R. Oswald. Glasgow M. J., 1894, xlii., 61.63.

and brain from microcephalio idiot. J. Wiglewworth. Liverpool M.-Chir. J., 1898, xiii., 500.

Care of the insane. Propused ohange of the legal status of the inseane, in accordance with our present knowledge of the nature of insanity, for the purpose of securing for them more rational and effoient treatment. $\mathbf{S}$. Bmith. Am. J. Insan., Utica, N. Y., 1893-4, 1., 825-344.

What improvements bave been wrought in the care of the ineane by means of training sobools P C. B. Burr. Ibid., 214-223.

The noed of special accommodation for. the degenerate. J. Morel. J. Ment., Sc., Lond., 1894, xl., 597-605.

On the separate treatment of recent and curable cases of ineanity in special detached hospitals, with plan and description of brildings about to be erected for this purpose at the Lancaster County Asylum, Whittingham. J. A. Wallis. Tbid., 385-844, 2 plans.

An outline of the progrese in the care and handling of the insane in the last twenty years. C. E. Riggs. J. Nerv. \& Ment. Dis., N.Y., 1898, xx., 620-628.

- Present hospital care of the insane. B. B. Lyon. Ibid., 1894, xxi., 604-511.

The institutional care of the insane. F. P. Christian. Physiojan \& Sur., Detroit \& Ann. Arbor, 1894, xvi., 208-215.

- (Colony Bystom of Gheel). Die familiale Verpflegung Goisteskranker (Bystem der Irren Colonie Gheel) der Irren-Anetalt der Btadt Berlin zu Dalldorf in den Jahren, 1885, bis 1898. Alfred Bothe. Berl, 1893, J. Springer, 162 p., 80.

The care and treatment of the insane in private practice. J. T. Wileon. Virginis M. Month., Richmond, 1893-4, xx., 1100-1116.

Ueber Fortsohritte in der Irrenpflege. Frederich Sobolz. Leipz., 1894, F. H. Mayer, 63 p., 80.

The care of the insane in Canada. C. K. Clarke. $\Delta \mathrm{m}$. J. Insan., Ution, N. Y., 1893-4, 1., 381.385.

Care of the insane in Finland. F. Hougberg. Ibid., 890-393.

Progress in the care and treatment of the incane during the half contury. Ih. Cowles. $\triangle \mathrm{m}$. J. Insan., Chicago, 1894-5, li., 10-22.

Cophalalgia. De la cóphalalgie dans les maladies mentales. A. Cullarro. $\Delta$ nn. méd.-perah., Par., 1894, 7 s., xx., 75-83.

Certification of lnnatics. Annual report on certification of lunatice, Barony Parish, Glasgow; together with some remarks on the annual report of the General Board of Commissioners in Lunacy for Bcotland. J. Carswell. Glesgow M. J., 1894, xlii., 846-852. 
Certification. Riaks to medical men cortifying under the Lanaoy $\Delta$ ot, 1890 . J. H. Gibson. Med. Times and Hosp. Gaz., Lond., 1894, xxii., 1., 481.

Childhood. Some mental disorders of childhood and youth. H. M. Hurd. Boston M. and B. J., 1894, oxrxi., 281-285.

The insane disorders of childhood. J. M. Taylor. Arch. Pediat., N. Y., 1894, xi., 100-115.

La folie chez l'enfant. P. Bézy. Mód. inf., Par., 1894, i., 75-84.

Caneation and early treatment of mental dieease in children. $\Lambda$. W. Wilmarth. J. $\Delta$ m. M. Ass., Chicago, 1894, xxiii., 271-274.

- Insanity in children. C. K. Mills. Med. Standard, Chicago, 1893, xir., 105-108.

Ineanity in children. Harriet C. B. Alexander. Alienist and Neurol., St. Louis, 1893, xir., 409; 1894, xv., 27. Also Woman's M. J., Toledo, 1894, ii., 18 ; 59. Also J. Am. M. Ass., Chicago, 1893, xxi., 511.519.

Some forms of insanity and quasi-insanity in children. C. K. Mills. Tr. M. Soo. Penn., Phila., 1893, xxiv., 204-213.

Chloralose. Le chloralose chez les aliénés. L. L'Hcest. Ann. Boc. méd. chir. de Liége, 1894, xxxiii., 290-298.

Chorea. Etat mental dans la chorée. A. Breton. Par., 1893, G. Steinheil. 118 p., 80.

Climacterio insanity. G. L. Sinclair. Internat. Clin., Philan, 1894, 3 s., iv., 147-152.

The insanity of the climacterio period. E. Goodall and M. Craig. J. Ment. So., Lond., 1894, xl., 235-242.

Colonies (insane). Les colonies d'alibnés. Riu. Cong. ann. de méd. ment., C.-r., 1892, Blois, 1893, iii., 63-70.

Commitment (The) of the insane. W. B. Whitwell. Tr. M. Soc. Calif., Ban. Fran., 1894, 223-235.

-The commitment, detention, care and treatment of the insane in Amerioa. G. A. Blumer. $\Lambda$ m. J. Insan., Utica, N. Y., 1893-4, 1., 588-656.

$\Delta$ plea for the voluntary commitment of the insane. C. E. Bigge. Northwest. Lancet, St. Paul, 1893, xiii., 206-209.

Confusional insanity. W. Worcester. Am. J. Insan., Chioago, 1894-5, li., $71-77$.

Congrés annuel de médeoine mentale. Troisième session tenue à Blois du ler au 6 août, 1892 . Compte.rendu par le dr. Doutrebente et le dr. Thiret. Blois, 1893, Dorion et Cie. 450 p., 80.

Contagion of insanity. De la contagion de la folie. de Boock. Soo. de mód. ment. de Bel., Gand et Leipz., 1893, 416-437.

- Des conditions de la contagion mentale morbide. Marandon de Montyel. Ann. méd.-poych., Par., 1894, 7. s., xix., 266 ; 466.

Convicts, insanity among. M. V. Ball. J. Am. M. $\Delta$ Bs., Chicago, 1893, xxi. 486-441.

Criminal lanatios. Des aliénés criminels ayant les apparences de raison. Rouby. Arch. d'anthrop. crim. Lyon et Par., 1894, ix., 338; 478.

- insanity among criminals. H. E. Allison. Am. J. Insan., Chicago, 1894-5, li., 54-63.

Ueber Behandlung and Unter bringung der irren Verbrecher. $\mathbf{R}_{\text {. }}$ Gtinther. Leipz., 1893, F. O. W. Vogel. 142 p., 80.

Degeneration. La valeur des signes de dégénérescence dans l'étude, des maladies mentales, P. Naecke. Ann. méd.-paych., Par., 1894, 7 s., xx. 250-261.

Dégénérescence. Max Nordau. Traduit de l'allemand par Angaste Dietrich. 2 vols. Par., 1894, F. Alcan. 437; 575 p., 80.

Dégéndrescenco mentale et ajndromes épisodiques multiples aveo delire polymorphe chez un même sujet. Magnan. Compt. rend. Boa. de biol., Par., 1894, 9 s., vi., pt. 2, 1.5. 
Delirium (aonte;, Beiträge zur Aetiologie und Pathogenese des Delirinm acutum. O. Basori. Centralbl. f. Bakteriol. n. Parasitenk., Jens, 1893, xiv., 609-616.

Delasional mania following injury; progressive mania. J. W. Springthorpe. Austral. M. J., Melbourne, 1893, n. s., xv., 527.529.

Dementia. Irritative dementia with bony thickening, following injury temporary improvement. J. W. Springthorpe. Anstral. M. J., Melbourne, 1893, n. 8., x7., 524.

- Contribution à l' étade de la démence précoco. A. Vigonronx. Ann. méd.-peych., Par., 1894, 7 s., xix., 62.70.

- (syphilitic). Report of a case of syphilitio dementia H. H. Herzog. Northwest. Lancet, St. Paul, 1894, xiv., 167-169.

(paralytica). Intorno a un caso di demenza paralitica combinats con afasia. G. Mingazzini. Bull. d. r. Accad. med. di Roma, 1892-3, xix., 156.167.

- paralytica in the negro. H. J. Berkley. Johns Hopkins Hosp. Bull., Balt., 1893, iv., 94-97; 1894, iv., 171-208, 1 pl.

- paralytica and neurasthenia. Zur differentialdiagnose der Dementia paralytica und der Neurasthenia cerebralis. R. von Krafft-Fbing. Festschr. z. Feier d. . . Jubil. d. Anst. Illenan, Heidelb., 1892, 65-76.

(paretic). Importance of early diagnosis in paretic dementia. C. W. King. Ohio M. J., Cinoin., 1894, v., 121-126.

The tropho-neuroses of paretio dementia. F. C. Hoyt. Am. J. Inean., Chicago, 1894-5, li., 51.53.

Dementia paralytica sine paralysi. J. Belkowsky. Centralbl. f. Nervenh. u Psychiat., Coblenz. u. Leipz., 1894, n. F., v., 169-176.

De herkenning van dementia paralytica, H. Buringh Boekhoudt. Haarlem, 1894, F. Bohn, 25 p., 80.

- (primary acute). Akute Stupidität (primäre heilbare Dementia Kraftt-Fbing). A. Hecker. Dentsche mil.-ärztl. Ztschr., Berl., 1893, xxii., 118-120.

(progressive). Démence progressive et incoordination des mourements dans les quatre membres, chez deux onfants, le frère et la scour. Bónchand. Rev. neurol., Par., 1894, ii., 2-7.

Detention hospitals for the insane. M. D. Field. Hosp., dispens., and nurs. ing. Internat. Cong. Char., 1893, Balt., Lond., 1894, 320-328.

Diagnosis. A case for diagnosis. R. H. Noott. J. Ment. So., Lond., 1894, xl., 49-52.

Dietetios in the treatment of the insane. J. M. Buchanan. Tr. Mississippi M. Ass., Jackeon, 1893, xxvi., 41-16.

Dress-fitting (Systematio) for female inmates of asylums. A. Finigan. J. Ment. Bc., Lond., 1893, xxxix., 200-203.

Duboisin. Des injections sous-cutanées de sulphate de duboisine en médecine mentale. J. Massant. Bull. Boo. de méd. ment. de Belg., Gand et Leipz., 1893, 407-415.

- Sulfate nentre de duboisine dans le traitement de l'aliénation mentale. Mabille et Lallement. Cong. ann. de mód. ment. C.-r. 1892, Blois, 1893, iii., 412-419.

Eipilepsy. Reflex disturbances in the cansation of epilepsy. W. C. Kranss. J. Nerv. \& Ment. Dis., N. Y., 1893, xx., 409-417.

- Paychioal epilepsy. S. J. Fort. Maryland M. J., Balt., 1893-4, xxx., 287-291. 4 lso Med. \& Surg. Reporter, Phila., 1994, lxx., 375-377.

Sensory and peychical epilepey. T. Diller. N. York M. J., 1894, lix., 898.

Ippilessia psiohica. G. Dotto. Pisani, Palermo (1892), 1893, xiii., 219-278, 1 diag. 
Inpilepery. The paychoses of. J. B. Stonehonse. Albany M. Ann., 1893, zir, 225-240.

Mental epilepsy. J. M. Mosher. J. Nerv. \& Ment. Dis., N. Y., 1898, xx., 398-408. Ll6o Tr. M. Soa. N. Y., Phila., 1893, 169-179.

State care of opileptios. J. B. Maxwell. N. Am. Pract., Ohicago, 1893, v., 531-535.

The need of special State provision for epileptios. J. Panton. Tr. M. Ass. Missonri, Jefferson City, 1893, 348-348.

- The epileptic interval: its phenomena, and their importance as a gaide to treatment. W. Browning. Tr. M. Soo. N. Y., Phila., 1893, 148-157. Also J. Nerv. and Ment. Dis., N. Y., 1898, xx., 369, 449, 528.

Genesi fisiologica dell' Epilepsie. L. Ronooroni. Arch. di paiohiat., etc., Torino, 1893, xiv., 83-114.

- De l'hospitalisation des épileptiques. Marandon de Montyel. Ann. méd..psych., Par., 1893, 7 s., xvii., 46-68.

- On the care of epileptics. F. Peterson. Am. J. Insan, Utica, N. Y., 1893-4, 1., 362-371.

- Some remarks on epilepsy ; and the care of epileptios on the colony plan. W. W. Drewry. Virginis M. Month., Biohmond, 1894-5, xxi., 477.492.

- Remarks upon the medioinsl treatment of ohronio epilepay. F. D. Bondurant. Am. J. Inesn., Chicago, 1894-5, li., 23.39.

Strontinm bromide in the treatment of chronio epilepey. H. J. Bortloy. Johns Hopkins Hosp. Bull., Balt., 1898, ir., 50.

- and insanity. Epilopeio and Geistesstörang. 0. Bleg. Deutrohe med. Wohnsohr., Loipz. a. Berl., 1893, xix., 1375-1878.

- hysteria and idiocy. Recherches oliniques et therrapentiques $\operatorname{mar}$ l'épilepeie, l'hystérie et l'idiotie. Compto rendu da servioo des onfants idiots, épileptiques et arrièrés de BioÁtro pondant l'ano6o. 1893, par Bourneville, aveo la collaboration de MM. Dauriac, Ferrier et Noir. Par., 1893, F. Alcan., 480 p., 15 pl., 80.

Ispileptio insanity. G. L. Sinclair. Internat. Olin., Phila., 1893, 8 ๕., i., 129-138.

J. H. MoBride. Rev. Insan. \& Nerv. Dis, Milwankee, 1893-4, iv., $1-20$.

- Folie épileptique; ivresse pathologique. Delbast6e. Presece mod. belge, Brax., 1894, xlvi., 257 ; 265.

nxoitement (Excensive mental) and some of its consequences. T. R. Glynn. Liverpool M.-Chir. J., 1894, xiv., 1-21.

Txpression in the insame, some further remarks on. J. Turner. J. Ment. BO, Lond., 1893, xxrix., 177-183, $1 \mathrm{pl}$.

Feeble-minded children. Sir D. Galton. Nineteenth Cent., Lond., 1894, xxxr., 276-283.

A diecussion on points connected with the education of feeble-minded ohildren. Brit. M. J., Lond., 1894, ii., 528-531.

The treatment of. F. Beach. Lancet, Lond., 1893, ii., 191.

Folie d denx. Aetiologie und Pathogenese des gemeinsohaftliohen Irreseins (folie à deux), van Deventer. [Transl.] Centralbl. f. Nervenb. u. Peyohiat., Coblenz. u. Leipz., 1893, n. F., iv., 161-173.

De la folie a deux et de ses trois grandes variétés oliniques. F. Marandon de Monyel. Gaz. d hôn., Par., 1894, lxvii., 702, 724, 752, 768. - La folie à deux; Ses diverses formes oliniques. F. L. Arnand. Ann. m6́.-psych., Par., 1893, 7 s., xvii., 337-875.

- A propos de folie d denx. F. L. Arnand. France mbd., Par., 1898, xl., 690-692.

Is folie d doux. de Boeck. J. de méd., ohir. et pharmsool., Brax., 1898, 886-988. 
CONTENTS OF No. 179.-OCTOBER, 1896.

PART I,-ORIGINAL ARTICLES.

W. Julius Miokle, M.D.-Presidentlat Addres.

George R. Wilsom, M.L.,The Significnnce of Wedsmann's Doctrine in Insastly.

J. F. Briscoe, M.R.C.S.-Heredity in Mental Disense.

R. S. Btewart M.D.-The Increase of Genoral Paralyats in Engind and Wales; its Cantation unu Btgnificdnce.

J. Maepherson, M.D.-Tlue Hopital Trantment of the Insune in Asylums.

A. R. Turnbull, X.B. $\rightarrow$ Note on Pemnle Nursing in an ABylum Male Sick Room.

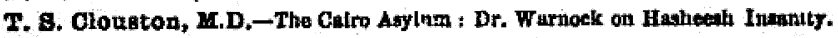

William W. Ireland, 2C.D.-Torquato Tasso and his Diographers.

Clintesl Notes and Cases,-A Case of Rechrrent Manta; by JoHs Q. Huvruck, M.D.

Occusional Noter of the Qzarter.-The Annual Meeting.- Retirement of Dr. Beach,-

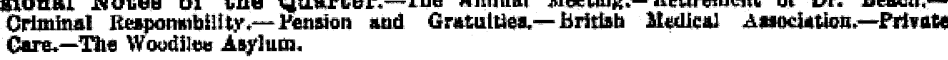

PART II.-PSYCHOLOGICAL RETROSPECT.

American Retrospect ; by Fuktcukz Bkack, y.D.

General lietroapect; by J. F. G. P1kxzhsen, M.R.C.S.

Crintnal antbropology ; by Havelock Elsts.

PART III.-NOTES AND NEWS.

Aruual Meeting of the HIellico-Paychological Associat'ou.-The Paychutogical Section of the Britinh

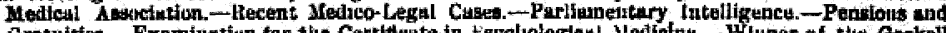

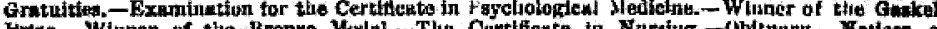
Moutings. A Appointments.-Index to Vol, xlji.

\section{CON'LENTS OF NO. 180.-JANUARY, 1897.}

PART I.-ORIGINAL ARTICLES.

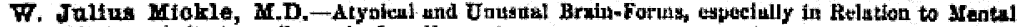

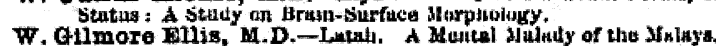

John Tarner, M.B. - Sume appearusces ladicattug l'nagocywsis observed in the Brains of the Imwne. Robert Jones, if.D. The London Councy Counell Agylum at Claybury, and a sketeh of fu first
Working Year.

J. J. Pitoalrn. L.R.O.P. - The Detectlon of Ilesanity In Privons.

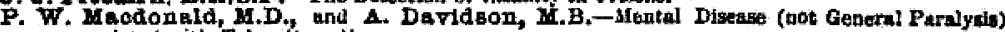

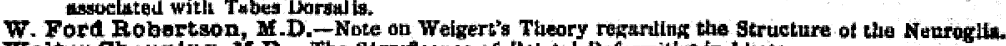
Waiter Channing, M.D. - The Stganfleanee of Palatal Defirmitiet in lchots.

J. Chriatian SImpson, M.D. -On l'ost-Operative Inswitlty.

H. Kornfeld, A.D. - Gil Mental Anto-infectuon.

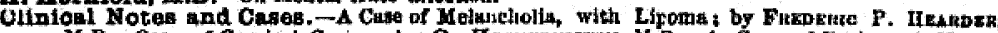

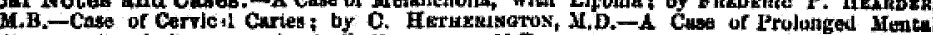
stupor ending in Hecarery; by A. E. PATrensos, M.D.

Ooorsional Notes of the Quarter.-Patlology in Asyloma-A Scottiah Proposu.--independent Orticism upon Histoloplcal Appearances in the Brulns of the Intane. - Housing the Insanes

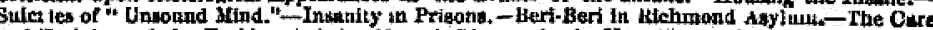
and Truining of the Fethle-rn!nded.-dental Diseases in the New Nomenciuture.

. PART II.-REVIEWS.

Firteth Report of the Commisaloners in Larsey for England,-Thirty-elghth Annual Report of the General Board of Comminstanera in Larucy for Scothand. - Forty-iffch Report of tha Inspectors

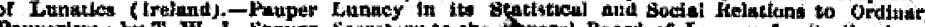

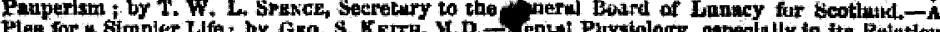

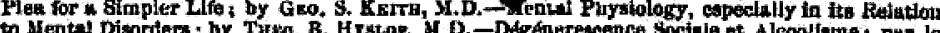
to Docher Chilith ; (ur The the

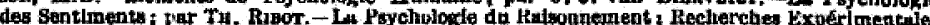
deser

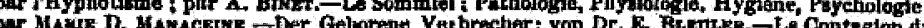

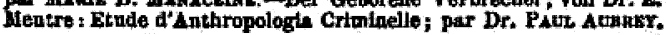

PART III.-PSYCHOLOGICAL RETROSPEOT.

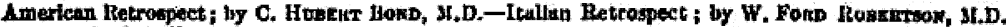
-Alylum lepportis.

PART IV.-NOTES AND NEWS.

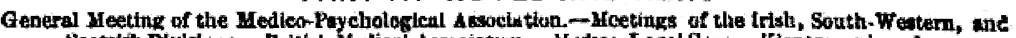

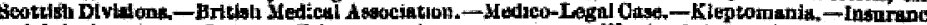

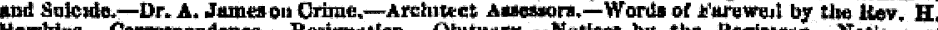

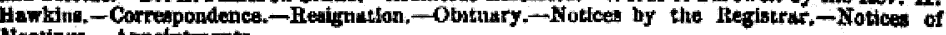
Heetingi-A $\mathbf{A p p o t n t m e n t s .}$ 


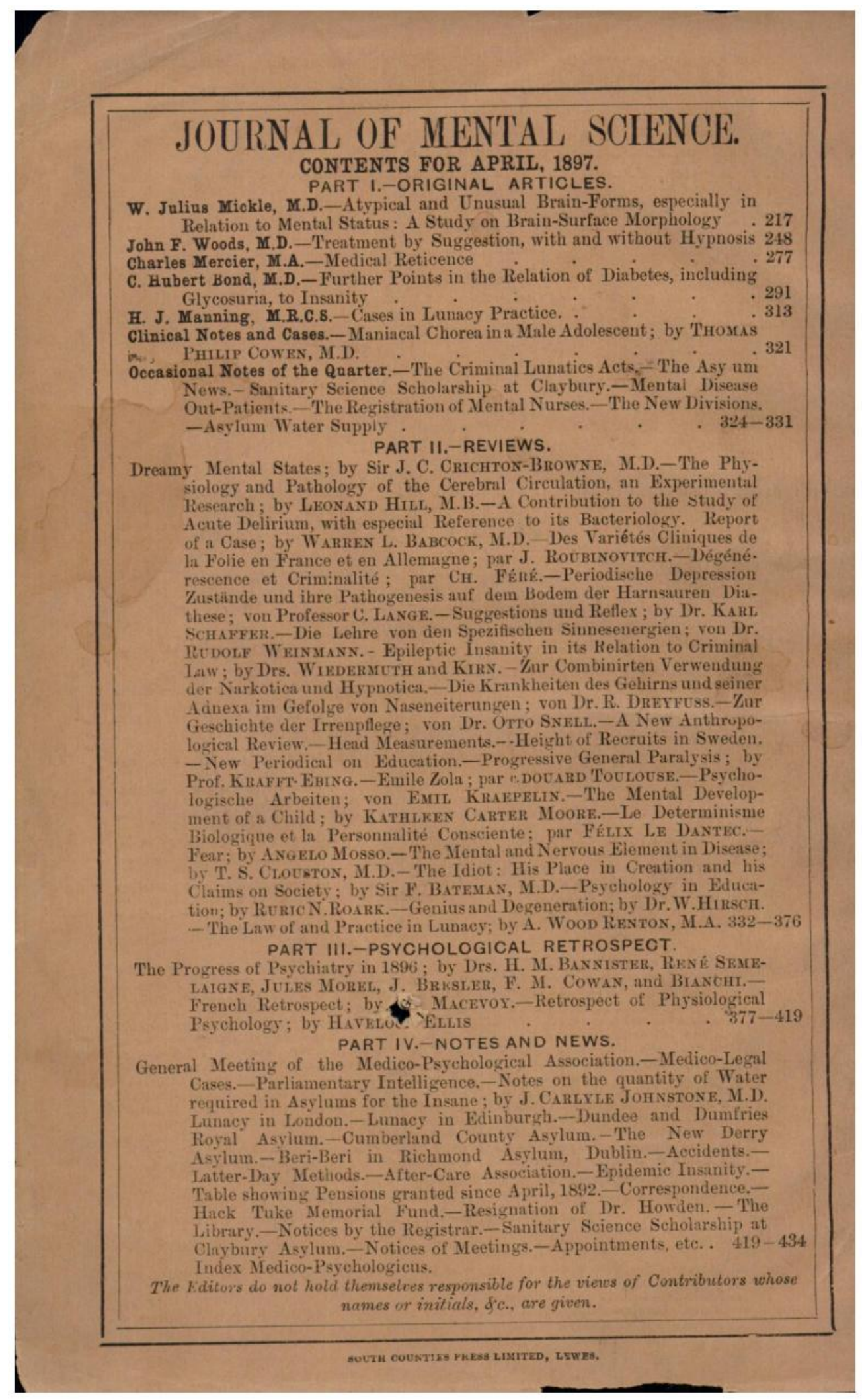

